\title{
Chapter 3 \\ Features of a Booming Reproductive Practice: The Medical Process, the Market, the Antecedents, and the Risks
}

\section{How It Happens}

Gestational surrogacy consists of implanting one or more embryos in the womb of a woman, who is not the supplier of the egg cells and will not be the social mother of the baby at the end of the pregnancy. The latter, at the moment of birth, is given to the intended parents, with usually at least one of the two being the supplier of the embryo's genetic heritage, and therefore the biological parent of the child. There are several actors in surrogacy transactions: fertility clinics, surrogacy firms or brokers, surrogacy agencies, egg supply agencies, in some cases also embryo transfer facilitators and counsellors (Klein, 2018).

Heterosexual couples generally rely on surrogacy when the woman cannot carry out a pregnancy due to medical conditions such as the absence of a uterus, congenital, or because it has been removed, when the woman suffers from fibroids, epilepsy, placenta accreta, or when she has previously had miscarriages (Guseva \& Lokshin, 2019). The surrogate must be pharmacologically prepared to host the embryos (SAMA, 2012) and a pre-implantation genetic diagnosis (PGD) is often made to ensure that there are no genetic diseases in the embryos (Jacobson, 2020). If more embryos successfully attach to the womb than the number of children desired by the couple, the surrogate will be asked to undergo a selective reduction of the embryos (Danna, 2014; Forman, 2015). During the pregnancy, the surrogate undergoes check-ups. The birth in most cases is planned and performed by caesarean section (Bromfield \& Rotabi, 2014; SAMA, 2012): in this way, the intended parents can be present at the time of birth. The child is immediately removed from the body of the woman who gave birth. The surrogate generally is not allowed to breastfeed in order to avoid excessive attachment with the newborn, although in some cases, she is asked to provide milk and even breastfeed as an extra service (Allen, 2018; Rotabi \& Bromfield, 2012; Saravanan, 2018; Sengupta, 2018).

The gametes with which the embryos are formed can come from the intended parents (both or only one) or from third-party suppliers (generally at least one of the 
two intended parents is also a biological parent). Heterosexual couples resort to gamete banks in the event that they cannot have a child with their own gametes or when they could transmit genetic diseases. In the case of surrogacy for a homosexual couple, the child is generally the genetic child of one of the two men. Homosexual couples also have the option of either mixing the sperm of the two men, or fertilizing the oocytes with the sperm of both partners and then transferring more embryos to the surrogate. The gametes supplied by third parties can be chosen from catalogues on the basis of physical and genetic characteristics, ethnicity and religion, character, talents, and life results obtained from the "donor" and his close relatives, characteristics that the aspiring parents hope can eventually be passed on to the child (Harrison, 2016; Twine, 2015). The suppliers of eggs are young women aged between 18 and 35: they are tested to make sure they do not have infectious diseases such as HIV, hepatitis, genetic problems and that they do not consume drugs; hormonal stimulation is then administered so that their bodies produce a greater number of oocytes (about twenty) than during a normal menstrual cycle in which each woman naturally matures one a month (Corradi, 2017); the oocytes are harvested through vaginal aspiration under sedation (Stoicea-Deram, 2016). The American Society for Reproductive Medicine (ASRM) states that there must be a valid justification to pay more than $\$ 5,000$ for an egg and more than $\$ 10,000$ is not appropriate compensation (Harrison, 2016).

The surrogates are recruited and selected by agencies specialized in surrogacy: a fundamental requirement is that they have already had a child, or that they have successfully had at least one pregnancy. They are chosen based on their appearance, body weight, social class, religion, and lifestyle (Saravanan, 2018). Their service is regulated by a contract, with which they undertake to carry out the pregnancy and hand over the baby at the time of delivery. The contracts can provide for various types of requests: for example, regarding nutrition, sport, housing conditions, trips to take or not to take during the pregnancy. The surrogate may be required to provide her medical records without any right of confidentiality. The contracts may also include medical screening of the surrogate's usual sexual partner. Furthermore, the contract may also provide for the termination of the pregnancy at the discretion of the intended parents (Danna, 2014; Forman, 2015).

The surrogates are usually paid in instalments at different stages of the process and receive additional rewards based on the number of foetuses. Prices vary from country to country: In the United States, surrogates earn between $\$ 20,000$ and $60,000^{1}$ and intended parents can spend more than $\$ 100,000$ if they use a surrogacy agency in the United States (Jacobson, 2016) and could save up to $70 \%$ less if they choose to undertake the whole process in the Global South (Esparza et al., 2014; Hernandez, 2018). In India, the price can drop to $€ 20,000$ and the surrogates receive

\footnotetext{
${ }^{1} 60,000$ US $\$$ is a base as base compensation for an experienced surrogate offered by a Californian agency. https://www.westcoastsurrogacy.com/become-a-surrogate-mother/surrogate-mothercompensation
} 
between $€ 3,500$ and 6,000, which they would earn in 5-7 years working any other type of job (Saravanan, 2018).

In some countries, only a reimbursement of expenses is allowed and not a real compensation. This modality is called gratuitous or altruistic surrogacy, to distinguish it from the commercial one (Van Zyl \& Walker, 2013). The name, however, must not be misleading: even when the surrogate does not receive a real compensation in money, the service received by the intended parents remains commercial as well as the activity carried out by the various professionals involved (lawyers, doctors, brokers) (Fabre-Magnan, 2013; Stoicea-Deram, 2016); furthermore, the compensation can also be of another nature, in the form of a gift, and not necessarily by virtue of what is established by a contract; finally, as will be discussed in greater detail in the next chapter, altruism, the pleasure of doing good to the couple by giving them the happiness of a child, is almost never the only motivation, or in any case alone, without other personal advantages, is not enough. There are also cases in which the surrogacy agreement is made between relatives (mother for a daughter or between brothers/sisters) or close friends, with or without mediation. However, even in these cases, it is not certain that the basis of the agreement is a pure motivation for help and a completely autonomous choice: even in the agreements between friends and relatives, there may be harassment, blackmail, or simply expectations of availability precisely by virtue of an emotional bond and gender roles in the family (Narayan, 1995).

In some cases, pregnant women spend the pregnancy in their own home, with their family, in others they move away from their community and spend 6-7 months together with other surrogates in clinics, dormitories, or small rented houses (Rudrappa, 2015). During the pregnancy, there may or may not be interaction between the surrogate and the intended parents, with it either being in person or electronically. The same goes for after childbirth: the surrogate is usually not present in the child's life, some intended parents may write or make video calls to keep each other updated on the well-being of the child and the life of the surrogate (Yee \& Librach, 2019).

\section{History}

Surrogacy is not the first method that humans have developed to procure a child out of natural conception between an adult couple who intend to become parents. Nor is it the only situation in which children are separated at birth from the women who give birth to them. Think of adoption, which is also often carried out in a transactional way. Consider servants who were made pregnant by masters who could not have a child by their wives. In Japan, this practice was called mekake-bouko: the servant, at the end of the working period, had to leave the child in the master's house; during the Meiji Government (1868-1912), these women were legally recognized as family members (Yanagihara, 2021). In Nigeria, there are baby factories where young women, consenting or not, are made pregnant to give birth to children who 
are sold to childless couples (Alabi, 2018). Surrogacy is also often compared to the custom of African and Asian children who are raised by relatives rather than natural parents (Segalen, 2021).

However, these are very different phenomena: surrogacy differs from each of these practices for various reasons. First of all, due to the use of biomedical technology as well as the fact that the parturient is not the biological mother of the child. Furthermore, surrogacy is distinguished from adoption in that the child is conceived specifically to be given to others: without this intention, the child would not exist. On the contrary, adoption is the solution to provide the child with parents when their biological ones cannot or do not want to take care of him: the child exists in any case, whether or not the intention of adopting parents. Among all these alternative methods of family formation, only adoption is comparable to surrogacy for having created a transnational market and having proposed itself as a mass practice. However, surrogacy is preferred to adoption for various reasons including the genetic link that the intended parents can have with the child, being able to have it with them from the first days of life, the streamlined procedures that in the case of adoption involves psychological checks of the couple, the shorter waiting times, and for greater control over the origin, health, and characteristics of the child (Rotabi \& Bromfield, 2012). Moreover, in many countries, adoption is not a viable path for homosexual couples and single people, categories of people for whom surrogacy becomes the only option (Smietana, 2018; Navarro, 2020).

The advent of reproductive technologies, initially developed in zootechnics and then also applied to human procreation, has made other methods available to circumvent the impossibility of having a child in a natural way. I propose dividing the techniques of assisted procreation into four levels, each one characterized by the overcoming of certain conditions (or limits) of natural procreation (Bandelli, 2019).

At the first level, there is artificial insemination. It allows for conception in the absence of any physical contact between two human beings of different sexes. At this level, conception is transformed from an intimate fact into a technical and artificial fact, in the hands of a third party who act as a mediator: the actions of the technicians (manipulation of the spermatozoa and insertion of these into the uterine cavity) replace the physical contact between the parents.

At the second level, there is in vitro fertilization (IVF), which can involve either the spontaneous union of the gametes or the introduction through a cannula of the sperm into the ovum (intracytoplasmic). The limit that is crossed in this second level is that of the corporeality of conception, which, in addition to taking place in the absence of any form of physical contact, also takes place outside the woman's body. The first human conceived with IVF was born in 1978: Louise Brown.

At the third level, there is heterologous fertilization, which can make use of both techniques seen so far. In heterologous fertilization, one of the two gametes does not belong to the pair of intended or social parents. In addition to being voluntaristic and relational, conception also pushes itself to produce a fragmentation of parenting and a self-attribution of the parental role dictated by the intention and not necessarily by the genetic link (Nicolussi, 2018). With heterologous fertilization, the following limits/conditions are exceeded: coincidence between biological and social parents; 
two-parenting (in the case in which the woman uses a donor and raises the child alone); two-parenting of different sexes (when the woman uses a donor to then raise the child with another woman); correspondence between pregnant woman and biological mother (if the oocytes do not belong to the pregnant woman).

At the fourth level, there is surrogacy. The unprecedented limit that this practice crosses lies in the unity between pregnant woman, biological mother, and social mother: surrogacy inevitably involves a newborn being removed from the body in which it developed for 9 months and being handed over to other people, of which at least one is usually its biological parent. It is an intrinsic fracture of practice (Allen, 2018) and is instrumental in the fulfilling of parental desire (the driving force of all levels of assisted reproduction). I will return to this point in the last paragraph of this chapter.

At the end of the 1970s, Noel Keane opened the first surrogacy agencies in Michigan, which in the mid-1980s became about 20 throughout the United States (Klein, 2018). At that time, however, the surrogates were also the biological mothers, i.e. they were inseminated with the gamete of the intended father. In 1985, the first child was born through the method called traditional surrogacy (Gueronzi, 2020). With the improvement of in vitro fertilization and embryo transfer, traditional surrogacy was replaced with the gestational form, in which embryos formed by the gametes of the intended parents and/or third-party suppliers are implanted in the woman. The absence of a genetic link between the pregnant woman and the child, as well as the direct implantation of the embryos (without contact between the gamete of the intended father and the body of the woman outside the couple) made it possible to relocate the surrogate from mother to a component of the "reproductive team" (Jacobson, 2016), making it less problematic to recognize the parental status of the clients.

Only this last form of surrogacy has led to a multimillion-dollar transnational market being created, along with a public discourse in which the need is claimed to make this method of family formation accessible and legal, as well as international working groups for its policy making. Official numbers on surrogate babies in the world do not exist (Jacobson, 2018): most of governments do not collect data on surrogacy births and there is no reliable information on which the scope of the phenomenon can be identified (Special Rapporteur, 2019). ${ }^{2}$ The International Social Service (ISS) NGO estimates 20,000 babies are born through surrogacy every year (de Aguirre, 2019). It is certain that this practice and the related market have been booming for about 10 years. According to the 2015 National Summary Report on Assisted Reproductive Technology, elaborated by Centers for Disease Control and Prevention, American Society for Reproductive Medicine, and Society for Assisted

\footnotetext{
${ }^{2}$ Following a call for inputs on surrogacy to governments, civil societies, and scholars, the United Nations Special Report on the sale and sexual exploitation of children in 2019 informed that only two governments have provided data on the number of surrogacy arrangements: In the United Kingdom, the number of parental orders following surrogacy was: 407 in 2016; 332 in 2017; and 176 in the first 6 months of 2018. In Australia, there were 139 cases of surrogacy undertaken abroad in 2016-2017 and 175 cases in 2017-2018 (Special Rapporteur, 2019, p. 11).
} 
Reproductive Technology (ASRM, 2015, p. 53), the number of transfers for ART cycles using gestational carriers more than doubled, from 2,251 in 2006 to 4,725 in 2015 , and the percentage of transfers using a gestational carrier among all transfers increased from about 2\% in 2006 to more than 3\% in 2015. 2,200 babies were born from surrogacy in America in 2014, more than twice as many as in 2007; if until 1992 , the total number of births through surrogacy worldwide was 4,000 , today only in India every year 3,000 babies are born (Danna, 2017).

Today, more and more would-be parents resort to this way of giving birth, not only attributable to the classic categories mentioned above (the heterosexual couple in which the woman cannot carry out a pregnancy due to medical reasons and homosexual couples): there are also single men and women who want to fulfil the desire of parenthood regardless of whether there have a partner in their lives (Johnson, 2015), celebrities and professional women who choose to delegate pregnancy so as to continue working. The latter case is defined social surrogacy. ${ }^{3}$ There are also more exceptional cases, such as when grandparents act as clients using the sperm or ova of the deceased child. ${ }^{4}$

The increasing spread of surrogacy is accompanied by its growing visibility in the public debate, linked to the claims of social movements and regulatory proposals, the chronicle of scandals, disputes for the legal recognition of parenthood, celebrities who undertake this method of filiation (i.e.: Cristiano Ronaldo, Elton John, Ricky Martin, Nicole Kidman, Kim Kardashian, and Sarah Jessica Parker) or cultural products such as TV series and films (i.e.: When the Bough Breaks, The New Normal, Top of the Lake: China Girl). The emergence of traditional surrogacy in the United States initially provoked reactions of dissent and mobilizations from feminists (Klein, 2018), which however were not sufficient to block its widespread diffusion, which as I have already explained occurred with the transition from traditional to gestational surrogacy. Now that surrogacy is no longer only an American phenomenon, but has spread to various parts of the world, the reactions of dissent, as we will see in the course of the book, have multiplied and are being organized both on a national basis and in transnational campaigns which demand its abolition.

Despite this, the regulatory orientation, more or less restrictive, prevails over the abolitionist orientation and surrogacy is normalizing as one of the methods available for having a child. Rodríguez-Jaume et al. (2021) from an analysis of 31 scientific articles on public opinion on surrogacy in different countries of the world, found that there is a general historical trend towards increasing levels of acceptance of the possibility of regulation. According to the review of Spanish sociologists, Canada, Japan, United Kingdom, Iran, Australia, and Spain are some of the countries where

\footnotetext{
${ }^{3}$ Check the following articles: https://www.conceptualoptions.com/what-is-social-surrogacy/ and https://www.theguardian.com/lifeandstyle/2019/may/25/having-a-child-doesnt-fit-womens-sched ule-the-future-of-surrogacy. Accessed 29 August 2020.

${ }^{4}$ See the story of Indian parents of a 27 -year man who died: https://www.bionews.org.uk/page 96375
} 
there is a higher level of acceptance of surrogacy, understood as a method of having a child for infertile couples. Nevertheless, it must also be said that among the various ways to have a child, surrogacy is the least accepted one, the so-called altruistic one more than the commercial one, the traditional one less than the gestational one (Kuchar, 2014).

Biomedical progress alone is not sufficient to explain the spread of surrogacy since the spread or not of a practice that the technique makes possible depends on conductive social factors (Rogers, 1995). Canadian sociologist Maria De Koninck identifies the following socio-cultural factors that encourage the social acceptance of surrogacy: within human rights paradigm and individualism "when some groups call for certain rights to be recognized, their denial is interpreted as discriminatory" (De Koninck, 2020, p. 30); one of the consequences of female emancipation is the raising of the age at which they become mothers, and with it a greater recourse to artificial procreation; procreation from "social duty" has become a "personal issue" (p. 31); the concept of child has changed: "as an extension of self rather than of bloodline, and this status is part of a social context that shapes people's desire both to have a child and to use all possible means to do so" (p. 32); the technique has invaded the reproductive life (e.g. the medicalization of pregnancy, birth control techniques); the feminist perspective that sees motherhood as an obstacle to emancipation and interprets gender identity as dissociated from one's own sex has spread; finally, neoliberalism and the logic of efficiency pervade private life. Those identified by De Koninck are also the ingredients of my reading of surrogacy that I will propose in Chaps. 8 and 9: a product of an individualistic society devoted to selfdetermination in which adult-centric discourses of reproductive autonomy and protection of women from commodification unfold.

\section{Laws and Markets}

The regulatory frameworks that the States adopt are extremely varied and inhomogeneous and no international agreement exists to date (Guzman, 2016; Mostowik, 2019; Torres et al., 2019; Stark, 2012). Some countries have laws that expressly prohibit any form of surrogacy (e.g. Italy, France, Spain, Switzerland, Germany, and Poland). Others only allow the so-called altruistic surrogacy (e.g. South Africa, Brazil, New Zealand, Iran, and Canada) and between relatives (e.g. India). Others also allow commercial surrogacy (e.g. Russia, Ukraine, and Israel). The law can establish the conditions under which it can be practiced: for example, only married couples can access it (e.g. Ukraine and Kazakhstan); the woman may be asked to prove the existence of health problems for which a pregnancy would involve a risk for her life and that of the child (e.g. Russia and Vietnam); in some laws, it is also established that the child must be the biological child of at least one of the two members of the couple; some States allow access only to citizens of the country (e.g. Thailand, India, Mexican State of Tabasco). There are also differences on how to register the birth: in Ukraine, for example, the intended parents are considered legal 
parents from the moment of conception; in other countries, the name of the woman giving birth is reported on the birth certificate (Mostowik, 2019). Furthermore, there is also the possibility, as in the case of Israel and Texas, that contracts must be validated by a State Committee. In States such as Spain, surrogacy contracts are instead considered null (de Aguirre, 2019). There are also States without any specific laws (e.g. Argentina, Belgium, Colombia, Kenya, Malaysia): this regulatory vacuum can give rise to different interpretations by the courts and even favour the development of the market.

This regulatory patchwork is constantly changing: to cope with the growing use of surrogacy and the speed with which its market is established and developed in a country, States adopt new laws. India has been a world leader in low-cost surrogacy since 2002, with an annual turnover of $\$ 400$ million and 3,000 fertility clinics operating in the country (Nixon \& Timms, 2017). Since 2012, the government has passed a series of laws aimed at containing the phenomenon: first it established access only to heterosexual couples who have been married for 2 years and later instituted a total ban on commercial surrogacy for foreigners, allowing only the altruistic form for Indian couples (Nixon \& Timms, 2017). There are other Asian countries that act along the same lines: in 2015, Thailand banned commercial surrogacy and the activity of intermediaries, allowing only free surrogacy to married Thai couples (Whittaker, 2016). In the same year, Nepal introduced a total ban, and Cambodia did so the following year (Bobrzyńska, 2019).

Following the closure of the Southeast Asian markets, low-cost surrogacy moved to Eastern Europe, Central Asia, Africa as well as Central and South America. Other countries, on the other hand, are moving in the opposite direction, towards greater openness. In 2014, Greece changed the citizenship or domicile requirement: if first both parties (intended parents and surrogate) had to have Greek citizenship or domicile in the country, from 2014, it is sufficient that one of the two parties has permanent or temporary residence in the country (Bobrzyńska, 2019). In 2016, Portugal legalized it. Since 2018, Israel has allowed surrogacy, not only to heterosexual married couples but also to single women as long as they provide the egg (Bobrzyńska, 2019).

Sociologist Sharmila Rudrappa explains how the market survives from bans and moves to less hostile countries: "The relatively small network of actors operating in India and Thailand, comprising proprietors of agencies that recruited intended parents, and medical business conglomerates scattered across the U.S., Australia, and Europe quickly restructured their business plans, and reached over to medical personnel across Russia, Ukraine, and the Republic of Georgia to start up once again the cycle of international clientele but now contracting with Russian, Ukrainian, and Georgian women as surrogate mothers. Thus, a few global actors and firms facilitate the rapid movement of the industry across a patchwork of nations, quickly making contacts with local medical personnel and moving clients into these new locations. Efficient networking is also provided by not-for-profit organizations that are market nodes which, through regular workshops, bring in parents with surrogated babies, potential intended parents, surrogate mothers who talk about their experiences, law 
firms, gamete banks, infertility clinics, and even insurance brokerage firms that cater to couples undergoing assisted reproduction" (Rudrappa, 2021, p. 290).

Sociologist Sheela Saravanan (2018) points out that many countries of the Global North have bans and effective implementation, while countries of the Global South have difficulty protecting themselves from uncontrolled market development. However, Saravanan also points out that the North-South movement is not enough to explain the configuration of the surrogacy market: indeed, it includes, for example, flows of would-be parents from Western Europe to Eastern Europe, and also the use of surrogacy by wealthy citizens and offered by poorer citizens, within the same country. The surrogacy request does not come only from Western Europe and North America: China is also among the emerging demand basins. According to Twine (2015) Chinese citizens use surrogacy services abroad, especially in the United States, to circumvent their country's restrictive parentage policies and secure American citizenship for their children.

Due to the diversity of regulatory frameworks from country to country, but also to the difference in costs, the surrogacy market has developed in a transnational way. Given the inextricable link between the procreative process and its market, the former can be read as a typical phenomenon of globalization (Inhorn \& Shrivastav, 2010): an economic and social organizational system based on the flows of goods, capital, and people in a world space made less and less distant by technological development, but also based on an accentuated social inequality between a global class of citizens of the world, who benefit from transnational space, and a class that instead remains imprisoned in its condition of local poverty (Beck, 1999).

The movement of people to take advantage of assisted procreation and surrogacy techniques from one country to another is often referred to as "reproductive tourism": Inhorn and Patrizio (2009) point out that since this expression evokes the fun of holidays, while the experience of people who do it is usually very expensive and stressful and faced due to "the desperate need of a child", it should be replaced with the notion of "reproductive exile" (Inhorn \& Patrizio, 2009, p. 905). On the other hand, however, it must be considered that the intended parents do not move only as a last resort (for example, when in their country surrogacy is prohibited, or allowed only in certain circumstances in which they do not fall): the countries are also chosen based on economic and logistical considerations, on the quality of the country's medical infrastructure, on the simplicity of bureaucratic procedures, on the ease in bringing the child to their own country with a suitable birth certificate or passport, on the personalization and ethics of the medical procedures offered, on the guarantees obtainable from the contracts, and on considerations regarding the geographical and cultural proximity with the surrogates (Jacobson, 2020; Saravanan, 2018). At this point, it is also worth clarifying that it is not only the intended parents who move, but also the gametes, embryos, and in some cases even the surrogates, who move to another country during the whole process or only for the implantation of the embryos or childbirth (Corradi, 2019; Schurr, 2018). ${ }^{5}$

\footnotetext{
${ }^{5}$ Varenikova, M. (2020). Mothers, babies stranded in Ukraine surrogacy industry. New York Times. Retrieved from https://www.nytimes.com/2020/08/15/world/europe/ukraine-baby-surrogate.html
} 
Faced with the acknowledgment that the practice exists and is widely used, even by citizens of countries where it is prohibited, the prohibitionist solution advocated with conviction by some groups of international civil society is struggling to establish itself as a viable approach to policy making. The regulatory approach, whether with a more restrictive intent or more oriented to facilitate access to the practice, is the most common orientation among both national and international policy makers (Torres et al., 2019; de Aguirre, 2019). The complete ban in some countries such as Italy, France, and Germany dates back to laws on medically assisted procreation developed when the practice had not yet reached today's levels of diffusion. These bans are now bulwarks of resistance but do not seem to serve as an applicable model to provide specific regulation for countries that do not have them yet or those in which the practice has spread in an uncertain legislative framework. In other words: obtaining a child through surrogacy is considered at most a possibility that can only be denied if certain conditions and requirements are not met, but not a practice to be prohibited in itself.

Two documents depart from this trend. The first one is the Model Law against Trafficking in Persons published by the United Nations Office on Drugs and Crime (UNODC) which suggested to include the use of women as surrogate mothers as a form of exploitation (Working Group on Trafficking in Persons, 2013). The second is the European Parliament's resolution that unequivocally "condemns the practice of surrogacy, which undermines the human dignity of the woman since her body and its reproductive functions are used as a commodity; considers that the practice of gestational surrogacy which involves reproductive exploitation and use of the human body for financial or other gain, in particular in the case of vulnerable women in developing countries, shall be prohibited and treated as a matter of urgency in human rights instruments" (European Parliament, 2015, p. 29).

There is a "sharp division" (de Aguirre, 2019, p. 476) among the members of the Parliamentary Assembly of the Council of Europe (PACE); in the October 2016 vote on the draft recommendation on Children's Rights Related to Surrogacy, with amendments which recommended a condemnation of all forms of surrogacy as well as a total international ban, neither the agreement with a complete ban as suggested by the draft nor the softer recommendation drawn up by the Committee on Social Affairs, Health and Sustainable Development of PACE was accepted: the latter dismissed the draft and adopted a shorter text in which the prohibition is not mentioned but simply recommended to the Committee of Ministers to consider the desirability of European guidelines to safeguard children rights and to collaborate with the Hague Conference on Private International Law (HCCH).

$\mathrm{HCCH}$ began work on the issue of surrogacy in 2010 noting that the application of the International Adoption Convention to surrogacy cases is improper. In 2015, the Expert Group was established to examine the feasibility of a multilateral instrument to regulate international surrogacy: recently in 2020, 200 women's rights organizations, 2,000 signatories from 50 countries participating in the International Coalition against Surrogate Motherhood (ICASM) called on the 86 Members of the 
$\mathrm{HCCH}$ to end the mandate of the Expert Group working on the parentage issue in the context of international surrogacy arrangements. ${ }^{6}$

Surrogacy is considered by the United Nations (UN) as a way for individuals and couples to fulfil their reproductive rights, with no UN agency having currently promoted any call for a total ban of commercial or the so-called altruistic surrogacy. Among the agencies that have worked on the issue, there is the UN population agency (UNFPA), which, however, does not have an official position on surrogacy: it has warned of the risks of exploitation for women as well as suggested that "more could also be done to raise awareness about preventing and addressing infertility, and in some countries to reform laws on infertility treatment, adoption and surrogacy in line with sexual and reproductive rights" (UNFPA, 2019, p. 123).

In 2019, the UNESCO International Bioethics Committee (IBC) released a report on assisted reproductive technologies and parenthood, in which the problematic aspects of surrogacy are underlined. For some members of the Committee, surrogacy should be rejected on the grounds of the risk of exploitation of the surrogate mothers, the best interest of the child, and the danger for the central position of the family as an institution. The report states: "the main argument for this position is that the lack of international legislation and adequate protection of commercial surrogates opens the door to violations of surrogates' rights. And furthermore, that surrogacy is incompatible with the protection and respect of the human dignity of surrogates" (IBC-UNESCO, 2019, p. 33). Other members of the committee argued that altruistic surrogacy under special conditions can be accepted, and a third group of members believe that "altruistic surrogacy could be acceptable in some specific cases but doubts whether the conditions required can be met in reality" (IBC-UNESCO, 2019, p. 33).

The UN agency that principally deals with the issue is the Office of the High Commissioner for Human Rights (Special Rapporteur, 2019): at the 37th session of the Human Rights Council, the Special Rapporteur Maud de Boer-Buquicchio presented the first ever thematic report on surrogacy and the sale of children within the UN human rights system. The report concluded that commercial surrogacy "could be conducted in a way that does not constitute the sale of children if it were clear that the surrogate mother was only being paid for gestational services and not for the transfer of the child" (Special Rapporteur, 2018, p. 17). This can be achieved, according to the report, by giving the surrogate mother the status of mother at birth and requiring a non-reimbursable payment for "surrogacy services" before the birth, in order to ensure that the surrogacy is, as the report says, "a gratuitous act" (Special Rapporteur, 2018, p. 18).

In the 2019 report to the General Assembly, the Special Rapporteur "reiterates the urgent need for holistic regulation of surrogacy, in particular when it comes to

\footnotetext{
${ }^{6}$ The ICASM petition is available at: https://docs.google.com/forms/d/e/ 1FAIpQLScjaCGzIRWLZz_kYS6Q0XbfzZHdZ1mAXDeKpHJaYTzKUPKDKg/viewform? gxids $=7757 \&$ mc_cid $=$ c50e $15531 \mathrm{~d} \& \mathrm{mc} \_$eid $=9 \mathrm{ff} 4 \mathrm{dcb} 521 \& \mathrm{fbclid}=\mathrm{IwAR} 1 \mathrm{hBsOOJ} 3 \mathrm{~L}$ o8gCETcxmRJOYHeevIuYkImumD0yoKafxhKcLPX-ee67JQ
} 
international surrogacy arrangements" (p. 16) and States are encouraged to "develop international norms through, for example, the Hague Conference on Private International Law project on parentage/surrogacy [..] to build bridges between different legal systems" (p. 19). The rationale of these recommendations is the need that the best interest of the child (and in particular certainty of identity, status, and parenthood) should be at the basis of any decision-making, in the case of both the prohibitive and permissive approaches: "it is imperative that States put in place clear frameworks for the protection of children [..]. In light of the global demand for surrogacy, even the most domestically prohibitive States must deal with the consequences of surrogacy arrangements" (Special Rapporteur, 2019, p. 6). However, in this document, it is also reminded that reproductive rights protected since the 1994 International Conference on Population and Development, include, according to the Inter-American Court of Human Rights, "the choice to procreate through assisted reproductive technologies" as "part of the rights to humane treatment and personal liberty and the rights of the family" (Special Rapporteur, 2019, p. 18).

The best interest of the child is also the approach of the European Court of Human Rights (ECHR): Cases submitted to the Court of Strasbourg raise issues mainly under Article 8 (right to respect for private and family life) of the European Convention on Human Rights. This is not the place to reconstruct the rulings so far issued by the Court on parental recognition in cases of surrogacy; However, I would like to report some observations by Carlos Martínez de Aguirre on the general approach of the Court. The Professor of Private Law at the University of Zaragoza notes that two circumstances are particularly relevant in orientating the Court: the existence of biological ties between the child and the intended parents, and the time that they have lived together. Furthermore, de Aguirre observes that the ECHR "has not expressed a clear position" and "states that its task is not to substitute itself for the competent national authorities in determining the most appropriate policy for regulating this issue": "the ECHR is aware that endorsing the conduct" of intended parents who engage in "reproductive tourism" to avoid national restrictive law "would be tantamount to legalizing the situation created by the intended parents, in breach of important rules of their national Law. That is why the ECHR emphasizes the relevance of the aims pursued by national Laws when banning or restricting surrogate motherhood" (de Aguirre, 2019, pp. 471-472).

\section{The Risks}

The previous sections discussed how surrogacy is a process that includes IVF, the implantation in the surrogate of an embryo formed by an egg foreign to her body, pharmacological treatments both in the egg provider and the pregnant woman, whose body must be artificially prepared for the embryo reception, selective reduction of "excess" embryos, the planning of a caesarean section, deprivation of health benefits (for both the woman and the child) given by breastfeeding, and always the detachment of the newborn child from the person in whom he grew up for 9 months. 
This process impacts on the health of both the surrogate and the baby, during and after birth, as well as the health of the egg provider, who can be the intended mother or a third party who sells her gametes on the fertility market. The egg provider, especially if treated more times, is at risk of ovarian hyper-stimulation syndrome, which might result in infertility problems (Cooper \& Waldby, 2014).

The number of adverse obstetric and perinatal outcomes, such as pre-eclampsia, placenta previa, premature birth, restriction of the growth of the foetus, and low birth weight, but also structural congenital anomalies (e.g. of the male urogenital system, gastrointestinal, and musculoskeletal systems), hypertension and cardiovascular problems, brain damage and intracranial pressure, and imprinting disorders are higher in artificial procreation (in vitro fertilization, intracytoplasmatic sperm injection, and (frozen) embryo implantation), than in a natural conception (Cooper \& Waldby, 2014; Darnovsky \& Beeson, 2014; Corradi, 2017, 2019; Weinrauch et al., 2018; Allen, 2018; Nicolau et al., 2015; SAMA, 2012; Woo et al., 2017). The greater number of these complications may be due to various factors including the state of infertility, the fact that artificial procreation has a higher rate of multiple gestations, the age of the mother, as well as the supra-physiological hormonal environment resulting from ovarian superovulation (Bellieni, 2019). Fertility treatment also increases the risk of miscarriages, stillbirths, as well as the possibility for offspring to develop neoplasms and cancer, particularly leukaemia and liver tumours (Corradi, 2019). From a health policy perspective, it should also be considered that deliveries from medically assisted procreation have a longer hospitalization time (Nicolau et al., 2015).

In addition to the risks related to artificial procreation techniques, surrogacy has some specific impacts on the child and woman's health, such as: greater vulnerability to cancer for surrogates, who due to pre-implantation hormonal treatments, selective embryo reduction, and caesarean section risk not being able to have other pregnancies in the future (Ness et al., 2002) and a higher incidence of post-partum depression (Ahmari et al., 2014; Lamba et al., 2018). ${ }^{7}$ It is also worth recalling that breastfeeding, which in surrogacy is prevented, along with skin-to-skin contact has the function of maintaining the maternal-foetal bond established during pregnancy, helps the woman to recover from giving birth, increases the infant's immune system, provides protection against infection, helps digestion and absorption of nutrients, and helps to protect the child from lung, intestinal, and tumour diseases in the years to come (Bellieni, 2019; WHO, 2009).

Furthermore, the effect of in vitro fertilization (and surrogacy) processes in the long term on the state of health of the human being, to be fully understood (Lozanski \& Shankar, 2019), requires large-scale follow-up and epidemiological studies, since hormonal stimulation and embryo culture produce epigenetic changes in the genes involved in growth and development (Bellieni, 2019). Cecilia Saccone, Emeritus Professor of Molecular Biology at the University of Bari, interviewed in 2017 by

\footnotetext{
${ }^{7}$ I recommend watching the following documentaries: Eggsploitation http://www.eggsploitation. com/about.htm and BigFertility http://www.cbc-network.org/bigfertility/
} 
feminist journalist Simonetta Robiony explained that "the mother transmits mitochondrial DNA that performs important biological functions, the main one being 'oxidative phosphorylation', the process whereby most of the energy that cells need is generated from breathing. The human species, like many animal species, has been provided by nature with a sort of 'quality control' to ensure that newborns are as healthy as possible. The practice of assisted pregnancy favours the meeting in vitro between the maternal oocyte and the paternal sperm to then implant the fertilized egg in the uterus. In this operation, the mitochondrial DNA, a 'small but beautiful' naked DNA, could suffer some damage or it could not perform its function of 'quality control' and not work. If the use of in vitro pregnancy were to spread exponentially, we could get to have a less vital, less strong, less energetic humanity. Or we could come to have two types of human beings: those born in vitro, weaker, dominated by those born according to nature, more energetic. Mitochondrial DNA is, in fact, what energizes our cells: damaged it would function badly". 8

Once the contract with the birth of the child is concluded, the surrogate, depending on the contract, might have to provide herself any medical treatment she may need. During the pregnancy, a woman's good health is functional to delivering a healthy baby, but after? In the press, there are countless testimonies of women who fell ill following one or more surrogacy pregnancies ${ }^{9}$; death is an inherent risk of surrogacy and the woman is required to declare in the contract she is aware of the medical risks, including death. ${ }^{10}$ In some contracts, it is provided that "if the surrogate is in her second or third trimester of pregnancy and in the event that medical life support equipment is required to preserve and maintain the life of the Surrogate and if requested by the Intended Parents, the Surrogate and her husband agree that the Surrogate's life will be sustained with life support equipment for a period to achieve viability of the foetus taking into account the best interests and well-being of the foetus. The Surrogate's husband, or her next of kin, is solely responsible for determining the time at which life support treatment will be discontinued following the birth of the Child" (de Aguirre, 2019, p. 459).

In the case the surrogate wants to bring a lawsuit, she needs to demonstrate that the cause of her illness is directly attributable to the medical procedures and pharmacological treatments to which she was subjected (e.g. repeated implantation of embryos before to remain pregnant, hormonal overdoses to increase the possibility of pregnancy, abortions of "excess" foetuses). It may also occur that the child is born with a pathology that could not be diagnosed during the pregnancy in time to decide to abort: in the media, there are reports of children abandoned by their

\footnotetext{
${ }^{8}$ http://www.cheliberta.it/2017/05/18/surrogata-e-assistita-la-scienziata-raccomanda-cautela/

${ }^{9}$ See the story of surrogate Tetiana Shulzhynska who in 2015 filed a complaint against a clinic in the Ukraine after having developed cervical cancer: https://www.theguardian.com/world/2020/jun/15/ the-stranded-babies-of-kyiv-and-the-women-who-give-birth-for-money

${ }^{10}$ See the story of Michelle Reaves who died from pregnancy-related complications in January 2020. http://www.cbc-network.org/2020/01/breaking-another-us-surrogate-mother-has-died/ Also, see the following article about contract assumption of risks https://collectif-corp.com/2019/ 02/28/y-compris-la-mort/
} 
intended parents in the country of birth, where they then are entrusted to orphanages. $^{11}$

Most of the risks mentioned so far may or may not occur and can be limited or prevented by intervening with medical procedures, through a market surveillance system and legal agreements, etc. However, there is a certain fact that is intrinsic to every surrogacy and cannot be prevented: the detachment of the child from the "environment" in which he began his psychophysical development. This detachment exists, regardless of the different value that we want to attribute to the maternalfoetal bond, to the legal status of the foetus, and regardless of any ethical, anthropological, or sociological discussion on the consequences of the interruption of this bond planned before conception.

The prominence that the genetic link has in the current socio-cultural paradigm of procreation obscures the fact that pregnancy, even when the woman does not provide the child with the genetic heritage, still remains a biological process and plays a very important role in the formation of the new human being (Françoise Héritier, in De Koninck, 2020; Gramolini, 2019). In an imaginary letter published by the New York Times in 2017, an intentional mother writes to the surrogate: "you will forever be imprinted on my child. He will have ingested your nutrients, felt your emotions. For his formative months, yours is the voice he will hear every day. Yours is the gait that will feel like home". These words find confirmation in the scientific knowledge on pregnancy and developmental psychology that explains the function of the maternal-foetal bond. In the uterus, the child's psychological, cognitive, and emotional development and the learning to relate to other people and space begin through a two-way exchange, which is biological, hormonal, physiological, and sensory with the woman, and continue in a continuum with birth. For example, the endometrial fluid regulates the transcription of the embryonic genome, the newborn recognizes the tone of the voice and the smell of the mother's milk, and the foetus makes intentional movements starting from the fourteenth week (Nicolais, 2018). During the pregnancy, childbirth and the first hours after birth, neuroendocrine changes are produced in women to prepare her for the care of the baby (Bascuñana, 2018; Mendiri, 2018): oxytocin is released in higher quantities for the production of milk as well as the establishment of the bond, with the sudden interruption of this bond possibly explaining why surrogates are at higher risk of post-partum depression. The relationship established during pregnancy is bidirectional and links the weaker subject to the stronger one, who will be identified by the first as a point of reference for learning, nourishment, and protection; it is a functional dialogue for the development of the new human being and for the regulation of mother and child in postnatal care (trans-modal correspondence) (Nicolais, 2018). This exchange is the foundation of the child's subjectivity as in it he learns how to relate to the other:

\footnotetext{
${ }^{11}$ For more details, see the report in Ukraine by the Australian Broadcasting Corporation (ABC): https://www.abc.net.au/news/2019-08-20/ukraines-commercial-surrogacy-industry-leaves-disas ter/11417388
} 
this grammar will serve him first for sharing emotional states and gestures, then for speaking.

Surrogacy deprives the weaker subject of the relationship with the party responsible for the continuation of his already started psychophysical development. Separating the dyad means forcing the infant to re-learn and overcome the shock of entering the social world without the reassurance of finding on the outside that one body that he already knows from within. The Swedish philosopher Marcus Agnafors (2014) points out that the fracture cannot be erased even if the child, thanks to his adaptive abilities and the love of the family, proceeds in a healthy way in his development. There are still too few studies to truly assess whether there are differences in the way surrogacy born children experience their childhood, adolescence, and adulthood, and it will take some time to assess the consequences of these births on social values and the conception of identity in relation to kinship. The longitudinal studies carried out by Golombok and colleagues give a non-problematic picture: according to the University of Cambridge team, not only do families formed in this way work well but in some parental performances are better than families in which children were naturally conceived and born: for example, in a study of 28 families formed through surrogacy (of which 35\% the intended mother is also the genetic mother), Golombok et al. (2017) concluded that mothers in surrogacy families showed less negative parenting, greater acceptance of their adolescent children, and fewer problems in family relationships as a whole. However, in a previous study (Golombok et al., 2011), they discovered that at age 7, there was less positive mother-child interaction in surrogacy families than the natural conception mother-child dyads and that the more positive parenting found when the children were in their preschool years was no longer apparent at age 7. A possible cause of this result according to the authors is that at that age children have a greater awareness of surrogacy.

These results do not change the fact that, as Agnafors pointed out, separation at birth from the surrogate is in itself a harm to the child: the happy ending does not cancel the intentionally created fracture, and this fracture itself represents harm to the child according to Agnafors: "pointing to apparently normal families and teenagers, or the potential or likely development into such, does not suffice to show that surrogacy involves no morally relevant harm, just as it cannot be proven that a man has not suffered a great harm when, say, losing a leg 10 years ago, by showing that he feels fine today, or that divorces are not harmful because children and parents are usually fully functional individuals in the long run" (Agnafors, 2014, p. 360).

Furthermore, it must be taken into serious consideration that the purposeful separation also produces a gap in the knowledge that the child will have of his history (Corradi, 2019). Laura Corradi, a sociologist expert in medically assisted procreation at the University of Calabria, points out that the secret creates an artificial psychological environment around the child who understands that something is hidden from him, even if he does not know what. However, even where the modality of his origin is revealed to the child, or the name of the woman who gave birth to him, through access to the original birth certificate, this remains mere information that the child will not be able to experience: the mere knowledge of the names of the 
parents and the surrogate is not enough to guarantee that child's right to know and be cared for by his or her parents, as it is enshrined in the Convention on the Rights of the Child and other international human rights instruments (Bandelli et al., 2020).

It is widely believed that the knowledge of origins is relevant only for children born from egg or sperm donation or given up for adoption, in other words that only the knowledge of genetic origins is relevant for the life of the child, while those of the woman who gave birth to him would not. The explanations given so far on the function of the biological and emotional exchange of pregnancy would already be sufficient to support the opposite. However, I want to add another aspect that makes bond maintenance important: epigenetics linked to family history. Epigenetics, which studies how the environment alters gene activity while not altering the DNA sequence, shows that, since there is an exchange between the molecules of the pregnant mother and the DNA of the embryo, the level of stress of the pregnant woman, the food she eats, the climate in which she lives, the hygienic conditions, the work she does, the pollutants, and other lifestyle factors affect the way the child's genes are expressed, and therefore also impact offspring for several generations (Fischbach \& Loike, 2014). Professor Francesco Montecchi, who specializes in child neuropsychiatry, links the theories of psychological transmission from one generation to another, to the epigenome and mitochondrial DNA already mentioned above: Montecchi recalls, through Sigmund Freud and Carl Gusav Jung, that the child is not a tabula rasa and who "is in possession of many things that he never acquired, but which he inherited from his ancestors", and which is a "link in a generational chain of which he is an instrument regardless of his will": "in surrogate pregnancy, with birth, prenatal emotional experiences undergo a caesura [..] The child has the mother's mitochondrial DNA [genetics], the epigenetic activation of the biological family [of the surrogate] which he then loses, after birth, as he goes to another family structure in which he does not find correspondence and continuity to the psychological and biological evolutionary process started during pregnancy" (Montecchi, 2016).

The theme of the fracture, understood as an inevitable harm for the child, will return in the course of the book, especially in Chaps. 8 and 9 in which I will argue the need to subordinate the desire of adults to have an offspring to the protection of the child.

\section{References}

Agnafors, M. (2014). The harm argument against surrogacy revisited: Two versions not to forget. Medicine, Health Care and Philosophy, 17(3), 357-363.

Ahmari, T. H., Tashi, S., Mehran, N., Eskandari, N., \& Dadkhah, T. T. (2014). Emotional experiences in surrogate mothers: A qualitative study. Iranian Journal of Reproductive Medicine, 12(7), 471.

Alabi, O. J. (2018). Socioeconomic dynamism and the growth of baby factories in Nigeria. SAGE Open, 8(2). https://doi.org/10.1177/2158244018779115. 
Allen, A. A. (2018). Surrogacy and limitations to freedom of contract: Toward being more fully human. Harvard Journal of Law \& Public Policy, 41(3), 753-811.

ASRM. (2015). National summary report. Retrieved from https://www.cdc.gov/art/reports/archive. html

Bandelli, D. (2019). Oltre noi stessi. Sociologia del limite nella procreazione medicalmente assistita. In D. Pacelli (Ed.), Il limite come canone interpretativo. Riflessioni e ambiti di applicazione a confronto (pp. 90-108). Franco Angeli.

Bandelli, D., Gennarini, S., \& Di Leo, E. (2020). Raising awareness on gestational surrogacy among vulnerable women in developing countries. Working paper for Development Cooperation agencies, International Organisations and NGOs. Retrieved from https://www.researchgate. net/publication/351302426_RAISING_AWARENESS_ON_GESTATIONAL_SURRO GACY_AMONG_VULNERABLE_WOMEN_IN_DEVELOPING_COUNTRIES

Bascuñana, G. M. (2018). Gestación subrogada: Aspectos emocionales y psicológicos en la mujer gestante. Revista Internacional de Eticas Aplicadas, 28, 41-49.

Beck, U. (1999). What is globalization? Polity Press.

Bellieni, C. (2019). Rischi per la salute dei figli nati da fecondazione in vitro. In L. Corradi (Ed.), Odissea embrionale. Fecondazione in vitro, eterologa e surroga di gravidanza: problemi di salute, giuridici e sociali. Mimesis [Kindle ed.].

Bobrzyńska, O. (2019). Surrogate motherhood: Current trends and the comparative perspective. In P. Mostowik (Ed.), Fundamental legal problems of surrogate motherhood: Global perspective (pp. 645-658). Wydawnictwo Instytutu Wymiaru Sprawiedliwości.

Bromfield, N. F., \& Rotabi, K. S. (2014). Global surrogacy, exploitation, human rights and international private law: A pragmatic stance and policy recommendations. Global Social Welfare, 1, 123-135.

Cooper, M., \& Waldby, C. (2014). Clinical labor: Tissue donors and research. Duke University Press.

Corradi, L. (2017). Nel ventre di un'altra. Una critica femminista delle tecnologie riproduttive. Castelvecchi.

Corradi, L. (2019). Fecondazione eterologa e surroga di gravidanza. In L. Corradi (Ed.), Odissea embrionale. Fecondazione in vitro, eterologa e surroga di gravidanza: problemi di salute, giuridici e sociali. Mimesis [Kindle ed].

Danna, D. (2014). «It's not their pregnancy». L'aborto nei contratti di maternità surrogata statunitensi. About Gender, 3(5), 139-173.

Danna, D. (2017). Maternità. Surrogata? Asterios.

Darnovsky, M., \& Beeson, D. (2014). Global surrogacy practices. Working paper N. 601. Thematic Area 5 International Forum on Intercountry Adoption and Global Surrogacy. ISSN 09210210.

de Aguirre, C. M. (2019). International surrogacy arrangements: A global "Handmaid's tale"? In P. Mostowik (Ed.), Fundamental legal problems of surrogate motherhood: Global perspective (pp. 449-485). Wydawnictwo Instytutu Wymiaru Sprawiedliwości.

De Koninck, M. (2020). Stolen motherhood. Surrogacy and made-to-order children. Baraka Books [Kindle ed.].

Esparza, M. B., Hernandez, P. C., \& Alcocer, A. R. (2014). Maternidad subrogada: Exploitacion de mujeres con fines reproductivos. Mujeres Independientes en Accion.

European Parliament. (2015). Annual report on human rights and democracy in the world 2014. A8-0344/2015. Retrieved from http://www.europarl.europa.eu/sides/getDoc.do?pubRef=-\% $2 \mathrm{f}$ $\%$ 2fEP\%2f\%2fTEXT\%2bREPORT\%2bA8-2015-0344\%2b0\%2bDOC\%2bXML $\% 2 \mathrm{bV0} \% 2 \mathrm{f} \%$ 2fEN\&language $=$ EN\#top

Fabre-Magnan, M. (2013). La gestation pour autrui: Fictions et réalité. Fayard.

Fischbach, R. L., \& Loike, J. D. (2014). Maternal-fetal cell transfer in surrogacy: Ties that bind. The American Journal of Bioethics, 14(5), 35-36.

Forman, D. (2015). Abortion clauses in surrogacy contracts: Insights from a case study. Family Law Quarterly, 49(1), 29-53. 
Golombok, S., Readings, J., Blake, L., Casey, P., Marks, A., \& Jadva, V. (2011). Families created through surrogacy: Mother-child relationships and children's psychological adjustment at age 7. American Psychological Association, 47(6). https://doi.org/10.1037/a0025292.

Golombok, S., Ilioi, E., Blake, L., Roman, G., \& Jadva, V. (2017). A longitudinal study of families formed through reproductive donation: Parent-adolescent relationships and adolescent adjustment at age 14. Developmental Psychology, 53(10). https://doi.org/10.1037/dev0000372.

Gramolini, C. (2019). Frattura scomposta. Il dibattito sulla surrogazione di maternità nel movimento lgbt+ italiano. In L. Corradi (Ed.), Fecondazione in vitro, eterologa e surroga di gravidanza: problemi di salute, giuridici e sociali. Mimesis [Kindle ed].

Gueronzi, C. S. (2020). Gift narratives of US surrogates. Italian Sociological Review, 10(3), 561-577.

Guseva, A., \& Lokshin, V. (2019). Medical conceptions of control in the field of commercial surrogacy in Kazakhstan. Salute e Società, 18(1), 26-43.

Guzman, V. R. (2016). A comparison of surrogacy laws of the U.S. To other countries: Should there be a uniform federal law permitting commercial surrogacy? Houston Journal of International Law, 38(2), 619-652.

Harrison, L. (2016). Brown bodies, white babies. The politics of cross-racial surrogacy. NYU Press.

Hernandez, Y. P. (2018). Gestación subrogada: una revisión etnográfica para contribuir al debate en México. Debate Feminista, 56, 85-109.

IBC-UNESCO. (2019). Report of the IBC on assisted reproductive technologies (art) and parenthood. SHS/IBC-26/19/2 REV. Retrieved from https://unesdoc.unesco.org/ark:/48223/ pf0000367957 (par. 168).

Inhorn, M. C., \& Patrizio, P. (2009). Rethinking reproductive "tourism" as reproductive "exile". Fertility and Sterility, 92(3), 904-906. https://doi.org/10.1016/j.fertnstert.2009.01.055.

Inhorn, M. C., \& Shrivastav, P. (2010). Globalization and reproductive tourism in the United Arab Emirates. Asia-Pacific Journal of Public Health, 22(3 suppl), 68S-74S.

Jacobson, H. (2016). Labor of love. Gestational surrogacy and the work of making babies. Rutgers University Press.

Jacobson, H. (2018). A limited market: The recruitment of gay men as surrogacy clients by the infertility industry in the USA. Reproductive Biomedicine and Society Online, 7, 14-23.

Jacobson, H. (2020). Cross-border reproductive care in the USA: Who comes, why do they come, what do they purchase? Reproductive BioMedicine and Society Online, 11, 42-47.

Johnson, M. K. (2015). Single, straight, wants kids: Media framing of single, heterosexual fatherhood via assisted reproduction. Journal of Gender Studies, 26, 387-405.

Klein, R. (2018). Surrogacy. A human rights violation. Spinifex Press.

Kuchar, P. (2014). The birth of surrogate motherhood law: An economic analysis of institutional reform. Paper presented at the International Society for New Institutional Economics conference (ISNIE), Durham.

Lamba, N., Jadva, V., Kadam, K., \& Golombok, S. (2018). The psychological well-being and prenatal bonding of gestational surrogates. Human Reproduction, 33(4), 646-653.

Lozanski, K., \& Shankar, I. (2019). Surrogates as risk or surrogates at risk? The contradictory constitution of surrogates' bodies in transnational surrogacy. Social Theory \& Health, 17, 4056.

Mendiri, M. A. A. (2018). Gestación subrogada desde una perspectiva biomédica: lo que el debate científico puede añadir a la discusión ética. Revista Internacional de Eticas Aplicadas, 28, 13-19.

Montecchi, F. (2016). Prefazione. In V. Bianchi Mian, S. G. Ceresa, \& S. Putti (Eds.), Utero in anima. Retrieved from https://www.psicheartesocieta.it/utero-in-anima/?fbclid= IwAR23j75dVv2CCtp_KDJkVgPPvm48qoxmZEgXD8T3dxiWLh1xB-65qlWrANk

Mostowik, P. (Ed.). (2019). Fundamental legal problems of surrogate motherhood: Global perspective. Wydawnictwo Instytutu Wymiaru Sprawiedliwości. 
Narayan, U. (1995). The 'gift' of a child: Commercial surrogacy, gift surrogacy and motherhood. In P. Boling (Ed.), Expecting trouble: Surrogacy, fetal abuse and new reproductive technologies (pp. 177-202). Westview Press.

Navarro, P. (2020). Surrogacy wars: Notes for a radical theory of the politics of reproduction. Journal of Homosexuality, 67(5), 577-599.

Ness, R. B., Cramer, D. W., Goodman, M. T., Kjaer, S. K., Mallin, K., Mosgaard, B. J., Purdie, D. M., Risch, H. A., Vergona, R., \& Wu, A. H. (2002). Infertility, fertility drugs, and ovarian cancer: A pooled analysis of case-control studies. American Journal of Epidemiology, 155(3), 217-224.

Nicolais, G. (2018). Il bambino capovolto. Per una psicologia dello sviluppo umano. Feltrinelli.

Nicolau, Y., Purkeypile, A., Meritt, A. T., Goldstein, M., \& Oshiro, B. (2015). Outcomes of surrogate pregnancies in California and hospital economics of surrogate maternity and newborn care. World Journal of Obstetrics and Gynecology, 4(4), 102-107.

Nicolussi, A. (2018). Famiglia e biodiritto civile, le parole del diritto. Scritti in onore di Carlo Castronovo. Jovene.

Nixon, J., \& Timms, O. (2017). The legal and moral debate leading to the ban of commercial surrogacy in India. Medicina e Morale, 4, 513-531.

Rodríguez-Jaume, M. J., González-Río, M. J., \& Jareño-Ruiz, D. (2021). Cross-border reproductive care: Opinions and attitudes of society towards surrogate pregnancy. Current Sociology, 69(2), 266-285.

Rogers, E. (1995). The diffusion of innovations. The Free Press.

Rotabi, K. S., \& Bromfield, N. F. (2012). The decline in intercountry adoptions and new practices of global surrogacy: Global exploitation and human rights concerns. Affilia, 27(2), 129-141.

Rudrappa, S. (2015). Discounted life: The price of global surrogacy in India. NYU Press.

Rudrappa, S. (2021). The impossibility of gendered justice through surrogacy bans. Current Sociology, 69(2), 286-299.

SAMA. (2012). Birthing a mother. A study on commercial surrogacy. SAMA.

Saravanan, S. (2018). A transnational feminist view on surrogacy. Springer.

Schurr, C. (2018). The baby business booms: Economic geographies of assisted reproduction. Geography Compass, 12(8), 1-15.

Segalen, M. (2021). Deconstructing social anthropology discourses in their support of surrogacy: The case of France. Current Sociology, 69(2), 176-192.

Sengupta, A. (2018). Surrogacy and breastfeeding. A puzzle to solve: A case study on the surrogacy industry in India. In A. A. Short, A. L. Palko, \& D. Irving (Eds.), Breastfeeding and culture: Discourses and representation (pp. 265-284). Demeter Press.

Smietana, M. (2018). Procreative consciousness in a global market: Gay men's paths to surrogacy in the USA. Symposium: Making families - Transnational surrogacy, queer kinship, and reproductive justice, $7,101-111$.

Special Rapporteur on the sale and sexual exploitation of children. (2018). Report to the Human Rights Council 37th session, A/HRC/37/60. Retrieved from https://undocs.org/en/A/HRC/37/60

Special Rapporteur on the sale and sexual exploitation of children. (2019). Report to the General Assembly 74th session. A/74/162. Retrieved from https://undocs.org/en/A/74/162

Stark, B. (2012). Transnational surrogacy and international human rights law. ILSA Journal of International \& Comparative Law, 18(2), 369-386.

Stoicea-Deram, A. L. (2016). Introduction: What is surrogacy for (East-European) feminism? Analize - Journal of Gender and Feminist Studies, 6, 3-11.

Torres, G., Shapiro, A., \& Mackey, T. K. (2019). A review of surrogate motherhood regulation in south American countries: Pointing to a need for an international legal framework. BMC Pregnancy and Childbirth, 19, 46. https://doi.org/10.1186/s12884-019-2182-1.

Twine, F. W. (2015). Outsourcing the womb race, class and gestational surrogacy in a global market. Routledge.

UNFPA. (2019). State of World Population 2019. Retrieved from https://www.unfpa.org/sites/ default/files/pub-pdf/UNFPA_PUB_2019_EN_State_of_World_Population.pdf 
Van Zyl, L., \& Walker, R. (2013 Sep). Beyond altruistic and commercial contract motherhood: The professional model. Bioethics, 27(7), 373-381.

Weinrauch, L. A., Gerhard-Herman, M. D., \& Mendelson, M. M. (2018). Epigenetics: Is the mode of conception a marker for future cardiovascular risk? Journal of the American College of Cardiology, 72(11), 1275-1277.

Whittaker, A. (2016). From «Mung Ming» to «Baby Gammy»: A local history of assisted reproduction in Thailand. Reproductive Biomedicine and Society Online, 2, 71-78.

WHO. (2009). Infant and young child feeding: Model chapter for textbooks for medical students and allied health professionals. World Health Organization; SESSION 2, The physiological basis of breastfeeding. Retrieved from https://www.ncbi.nlm.nih.gov/books/NBK148970/

Woo, I., Hindoyan, R., Landay, M., Ho, J., \& Ingles, S. A. (2017). Perinatal outcomes after natural conception versus in vitro fertilization (IVF) in gestational surrogates: A model to evaluate IVF treatment versus maternal effects. Fertility and Sterility, 108(6), 993-998.

Working Group on Trafficking in Persons. (2013). Forms of exploitation not specifically mentioned in the protocol. CTOC/COP/WG.4/2013/4. Retrieved from https://www.unodc.org/unodc/en/ treaties/CTOC/working-group-on-trafficking-2013.html

Yanagihara, J. (2021). The practice of surrogacy as a phenomenon of 'bare life': An analysis of the Japanese case applying Agamben's theory. Current Sociology, 69(2), 231-248.

Yee, S., \& Librach, C. L. (2019). Analysis of gestational surrogates' birthing experiences and relationships with intended parents during pregnancy and post-birth. Birth, 46, 628-637.

Open Access This chapter is licensed under the terms of the Creative Commons Attribution 4.0 International License (http://creativecommons.org/licenses/by/4.0/), which permits use, sharing, adaptation, distribution and reproduction in any medium or format, as long as you give appropriate credit to the original author(s) and the source, provide a link to the Creative Commons license and indicate if changes were made.

The images or other third party material in this chapter are included in the chapter's Creative Commons license, unless indicated otherwise in a credit line to the material. If material is not included in the chapter's Creative Commons license and your intended use is not permitted by statutory regulation or exceeds the permitted use, you will need to obtain permission directly from the copyright holder.

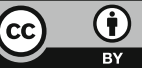

